\title{
Evaluation of Analgesic Effect of Apigenin in Rodent
}

\author{
Arka Mondal, Harihar Dikshit, Lalit Mohan, Dr.Hitesh Mishra*, Manish Kumar, Margoob Ahmad, Manoj Kumar \\ Department of Pharmacology, Indira Gandhi Institute of Medical Science, Sheikhupura, Patna-800014, India. \\ *Corresponding author's E-mail: arkam741@gmail.com
}

Received: 14-10-2021; Revised: 21-12-2021; Accepted: 29-12-2021; Published on: 15-01-2022.

\begin{abstract}
In Chronic inflammatory and painful diseases, such as Osteoarthritis, Rheumatoid arthritis, Low back pain, Fibromyalgia drugs that are currently used for the treatment of pain are opioids and for inflammatory conditions are non-steroidal anti-inflammatory drugs (NSAIDs) and corticosteroids. All these drugs produce potential toxic effects. Apigenin, a naturally occurring plant flavone, abundantly present in common fruits and vegetables, is recognized as a bioactive flavonoid. Current study envisaged analgesic properties of apigenin in animal models. Three dose, $10 \mathrm{mg} / \mathrm{kg}, 20 \mathrm{mg} / \mathrm{kg}$ and $40 \mathrm{mg} / \mathrm{kg}$ of apigenin were used in this study. Analgesic activity was studied in rat and mice by radiant tail-flick and Eddys hot plate models respectively. In both models the standard drug used was Tramadol- $25 \mathrm{mg} / \mathrm{kg}$. The optimal analgesic effect of apigenin can be seen at dose $20 \mathrm{mg} / \mathrm{Kg}$ in tail-flick $(\mathrm{P}<0.05)$ and Eddy's Hot plate model $(\mathrm{P}<0.05)$ in comparison to control and standard drug respectably. In conclusion Apigenin processes analgesic activities.
\end{abstract}

Keywords: Apigenin, NSAID's, Analgesic activity, Flavonoids.

QUICK RESPONSE CODE $\rightarrow$

DOI:

10.47583/ijpsrr.2022.v72i01.021

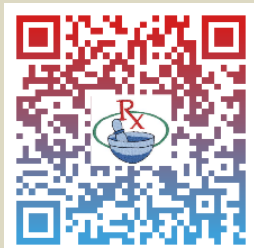

DOI link: http://dx.doi.org/10.47583/ijpsrr.2022.v72i01.021

\section{INTRODUCTION}

Igesia or pain is an unpleasant bodily sensation perceived as suffering, usually evoked by an external or internal noxious stimulus ${ }^{1}$. Failure to relieve pain is

morally and ethically unacceptable. Drugs that are currently used for the treatment of pain are opioids and for inflammatory conditions are non-steroidal antiinflammatory drugs (NSAIDs) and corticosteroids ${ }^{2}$. All these drugs produce potential toxic effects. Different study suggests that risk of gastrointestinal bleeding, allergic reactions, renal failure was significantly associated with use of non-steroidal anti-inflammatory drugs (NSAIDs) like regular-dose aspirin, diclofenac, ketorolac, naproxen or Nimesulide ${ }^{3,4}$. NSAIDs with longer half-lives are more likely to cause nephrotoxicity because of sustained prostaglandin inhibition leading to a sustained reduction in renal blood flow ${ }^{5}$. Ibuprofen-associated with acute, reversible renal failure with hyperkalemia, tubular necrosis, and proteinuria developed in a patient who had no predisposing underlying disease ${ }^{6}$.

It is not unexpected that from drug discovery to market most compounds face an uplift battle to become an approved drug. Drug research and development (R \& D) is comprehensive, expensive, time-consuming process with full of risk. It is far estimated that a drug from concept to market would take approximately 10 to 12 years with huge capitalizing out of-pocket costs ${ }^{7}$.

On the contrary many medicines of plant origin had been used since ages with minimal adverse effects profile than traditional analgesic drugs. It is therefore essential to introduce new plant metabolites like flavonoids to develop more effective and cheaper drugs $^{8}$. Flavonoids are an important class of natural products; especially, they belong to a class of plant secondary metabolites having a polyphenolic structure, widely found in fruits, vegetables and certain beverages ${ }^{9}$. Flavonoids had long been recognized as potential anti-inflammatory, antioxidant, antiviral, antimicrobial, and antiallergic molecules. Flavonoids provide an important nutraceutical component to our diet and apigenin is one of them. ${ }^{10}$.

In the present Study Apigenin was selected as plant flavonoids because of diverse action of the molecule. occurring glycosides Apigenin (4,5,7-trihydroxyflavone) is one of the most widespread flavonoids in plants and formally belongs to the flavone sub-class that is the aglycone of several naturally. It is a yellow crystalline solid that had been used to dye wool ${ }^{11}$. It was widely used in the treatment of various neoplastic disease includes ovarian cancer $^{12}$, breast cancer ${ }^{13}$, colorectal cancer $^{14} \&$ various inflammatory and lipid disorders like multiple sclerosis, Amnesia and Alzheimer's Disease ${ }^{15}$.

Up to date no pre-clinical pharmacological study has been systematically conducted in animal models to evaluate the analgesic action of apigenin supporting traditional uses of this nutraceutical as dietary supplementation. 


\section{MATERIALS AND METHODS}

Description of plant flavonoid: - Apigenin was procured from Sigma pharmaceuticals pvt.Itd. as a powder.

Selection of animals, caring and handling: - A total of 30 healthy Wistar albino rats (90-150 g), of either sex and 30 healthy Swiss albino mice weighing 25-30 gm of either sex obtained from the Central Animal house IGIMS, Patna India were used in the experiments. Male \& female Animals were separated in different cages. Animals were housed in polypropylene cage containing sterile paddy husk (procured locally) not more than 6 animals per cage under standard conditions of temperature $\left(23 \pm 3^{\circ} \mathrm{C}\right)$, humidity and 12 hours natural light and 12 hours Natural dark cycle. Animals were acclimatized for 7 days to the laboratory conditions before experiment. Animals were given standard dry pellet diet and tap water ad libitum. One day before the experiment animals were deprived of food as this is known to enhance their motivation to perform the test. For easy identification of animals in every group tail had been colored. The study was undertaken after obtaining approval of Institutional Animal Ethics Committee (IAEC approval Letter No. 125/2018/Pharma/IAEC/IGIMS dated 14/12/2018).

Study design: -The rats were randomly allocated into five groups of six rats for one model for testing analgesic activity. Mice were also divided into five groups of six mice each for the one experimental animal model of analgesia.

\section{Grouping of Animals for Analgesic Study:-}

Group I (control) received Normal Saline $2 \mathrm{ml}$ of each rat (tail flick model) \& mice (Hot plate model) perorally through intragastric tube.

Group II received standard drug Tramadol $25 \mathrm{mg} / \mathrm{kg}$ intraperitoneally according to different body weight.

Group III received apigenin $10 \mathrm{mg} / \mathrm{kg}$ per orally

Group IV received apigenin $20 \mathrm{mg} / \mathrm{kg}$ per orally

Group $\mathrm{V}$ received apigenin $40 \mathrm{mg} / \mathrm{kg}$ per orally

\section{MATERIALS}

Drugs: Tramadol, Normal saline, Ether (Sigma chemical Co. St Louis, USA, Apigenin

Instruments: Eddy's hot plate Analgesiometer: (Instruments \& chemicals pvt. Ltd model town Ambala city), Tail flick- Analgesiometer- (Instruments \& chemicals pvt. Ltd model town Ambala city).

Determination of the drug dosage and dosing schedule: Doses were selected and determined according to the previous acute toxicity studies ${ }^{16}$. Three different doses were selected $10 \mathrm{mg} / \mathrm{kg}, 20 \mathrm{mg} / \mathrm{kg}$ and $40 \mathrm{mg} / \mathrm{kg}$ for analgesic activities. Before staring the experiment preparation of stock solution of apigenin was done by dissolving the apigenin powder in normal saline and administered according to animal body weight of each model.

\section{METHODS}

\section{Analgesic study}

Radiant heat tail-flick method: - The central analgesic activity was determined by radiant heat tail-flick model in rats17. The tail is the most important thermoregulatory organ of the rat. The heat dissipation is regulated by an onoff regulation of blood flow in the tail. The analgesic activity of the apigenin was studied by measuring druginduced changes in the sensitivity of the pre-screened rats (the intensity of the light beam was experimentally defined such that animals withdraw their tails within 2 to 4 s) to heat stress applied to their tails by using analgesiometer. Tail-flick latency was assessed by the analgesiometer. All drugs were given in respective group in a respective route. The strength of the current passing through the naked nichrome wire was kept constant at 5 amperes. The distance between heat source and the tail kept $1.5 \mathrm{~cm}$ and the application site of the heat on the tail was maintained within $2 \mathrm{~cm}$, measured from the root of the tail. Cut-off reaction time was $+10 \mathrm{~s}$ to avoid any tissue injury during the process.

Evaluation: - The time taken by rats to withdraw (flick) the tail was taken as the reaction time. The animals were subjected to the same test procedure at $+0 \mathrm{~min}$ without administering any drug considered as basal followed by $+30,+60,+120$, and +180 min after the administration of test/standard/ control drug.

Eddy's Hot plate method: - The analgesic activity of the Apigenin, was measured by hot-plate method. The hot plate test involves higher brain function, and is considered to be a supraspinally organized response. The paws of mice are sensitive to heat at temperature which are not damaging to skin. The responses are jumping, withdrawal of the paws and licking of the paws. The mice were placed on a hot plate maintained at $55 \pm 0.5^{\circ} \mathrm{C}$. Basal reaction time was taken when mice start licking their paw or started jumping, which was appearing first. The normal reaction time was around 7-9 sec. Hotplate latency was assessed by the analgesiometer. All drugs were given in respective group in a respective route.

Evaluation: - The reaction time was recorded without administering any drug considered as basal followed by $+30 \mathrm{~min}$, +60min, $+120 \mathrm{~min}$, $+180 \mathrm{~min}$ after the drug administration. The cut-off time was considered as 15 seconds in order to avoid burning of the animals. The mean reaction time for each treated group was determined and compared with that obtained for each group before treatment. Percentage increase in reaction time $(1 \%)$, was derived, using the formula

$\mathrm{l} \%=\{(\mathrm{It}-\mathrm{lo}) / \mathrm{lo}\} \times 100$,

Where $\mathrm{It}=$ reaction time at time $\mathrm{t}$, and $\mathrm{lo}=$ reaction time at time zero $(0 \mathrm{~h})^{18}$.

Statistical analysis: - The results were analysed for mean $\pm S E M, S D$ statistical significance using One way 
ANOVA, followed by Scheffe's test. A P-value $<0.05$ was considered significant.

\section{RESULTS}

\section{Analgesic activity in rats by Radiant heat tail-flick method}

Latency period at different time interval significantly different $(p<0.01 \& p<0.001)$ compared to baseline values within the same drug treated group. Tramadol and Apigenin all dose caused significant dose dependent increase $(P<0.05)$ in the percentage reaction time throughout the experiment. Although $20 \mathrm{mg} / \mathrm{kg}$ body weight showing maximal inhibition of pain response activity at 120 minutes. Table 1 shows the Analgesic effect using radiant tail-flik method in Wister albino rat. The percentage increase in reaction time was dose dependent. At all the specific time intervals the percentage of tail flick elongation time differed significantly between the different dose of apigenin and Tramadol ${ }^{19}$. At the peak of activity Apigenin-20mg/kg showed 74.79\% $\quad(P<0.001)$.
Percentage of tail-flik elongation time while Tramadol gave $11.05 \%(P<0.05)$ percentage of tail-flik elongation time (Table-1).

\section{Analgesic activity in mice by Eddy's Hot plate method}

In Hot plate method both the Apigenin and standard drug Tramadol caused significant increase $(P<0.05)$ in reaction time. The increase in latency period in different time intervals significantly differed compared to baseline value within the same drug treated group. The percentage increase in the reaction time was dose dependent and differed significantly among the groups of mice $(P<0.001)$ receiving different dose levels of the apigenin and Tramadol. The percentage increase in the reaction time caused by the apigenin-20mg, apigenin-40mg and tramadol was detectable and peaked, at $+2 \mathrm{hr}$. and $+3 \mathrm{hr}$. The percentage increase in the reaction time for apigenin$10 \mathrm{mg}$ was peaked at $+2 \mathrm{hr}$. but thereafter declined at $+3 \mathrm{hr}$.

Table 1: Effect of apigenin on radiant heat tail flick model in rat

\begin{tabular}{|c|c|c|c|c|c|c|}
\hline \multirow[b]{3}{*}{ Drug } & \multicolumn{6}{|c|}{ Analgesic effect of Apigenin on radiant heat tail-flick response in rats } \\
\hline & \multicolumn{6}{|c|}{ Reaction time in a sec (mean \pm SEM), SD, Percentage Elongation } \\
\hline & Dose/route & Basal & $\begin{array}{c}\text { 30min } \\
\text { \% Elongation }\end{array}$ & $\begin{array}{c}\text { 60min } \\
\% \text { Elongation }\end{array}$ & $\begin{array}{c}\text { 120min } \\
\text { \% Elongation }\end{array}$ & $\begin{array}{c}\text { 180min } \\
\text { \% Elongation }\end{array}$ \\
\hline $\begin{array}{l}\text { Normal saline } \\
\text { (control) }\end{array}$ & $2 \mathrm{ml}$ P.O. & $\begin{array}{c}3.8 \pm 0.6 \\
(1.602)\end{array}$ & $\begin{array}{c}3.8 \pm 0.3 \\
(0.752), 0 \%\end{array}$ & $\begin{array}{c}3.8 \pm 0.3 \\
(0.752), 1.73 \%\end{array}$ & $\begin{array}{c}4.1 \pm 0.6 \\
(1.471), 7.89 \%\end{array}$ & $\begin{array}{c}4.6 \pm 0.7 \\
(1.861), 21 \%\end{array}$ \\
\hline $\begin{array}{l}\text { Tramadol } \\
\text { (Standard) }\end{array}$ & $25 \mathrm{mg} / \mathrm{kg}$ I.P. & $\begin{array}{c}19 \pm 1.5 \\
(2)\end{array}$ & $\begin{array}{c}19 \pm 1.5^{*} \\
(3.687), 0 \%\end{array}$ & $\begin{array}{l}19.33 \pm 1.1^{* *} \\
(2.732), 1.73 \%\end{array}$ & $\begin{array}{c}21.1 \pm 0.7^{*} \\
(1.940), 11.05 \%\end{array}$ & $\begin{array}{c}20.8 \pm 0.6 \\
(1.471), 9.47 \%\end{array}$ \\
\hline Apigenin-10mg & $10 \mathrm{mg} / \mathrm{kg}$ P.O. & $\begin{array}{c}10.3 \pm 1.9 \\
(4.718)\end{array}$ & $\begin{array}{c}10.6 \pm 1.2 * \\
(2.943), 2.9 \%\end{array}$ & $\begin{array}{c}11.3 \pm 0.8^{* *} \\
(2.065), 9.70 \%\end{array}$ & $\begin{array}{c}14.1 \pm 1.6 \\
(3.970), 36.89 \%\end{array}$ & $\begin{array}{c}13.1 \pm 0.76 \\
(1.834) \mathbf{2 7 . 1 8 \%}\end{array}$ \\
\hline Apigenin-20mg & $20 \mathrm{mg} / \mathrm{kg}$ P.O. & $\begin{array}{c}12.3 \pm 1.1 \\
(2.875)\end{array}$ & $\begin{array}{c}18.6 \pm 0.9^{*} \\
(2.338), 51.21 \%\end{array}$ & $\begin{array}{c}19.1 \pm 1.0 \\
(2.639), 55.28 \%\end{array}$ & $\begin{array}{c}21.5 \pm 0.6 \\
(2.516), 74.79 \%\end{array}$ & $\begin{array}{c}21 \pm 1.5 \\
(2.828), 70.73 \%\end{array}$ \\
\hline Apigenin-40mg & $40 \mathrm{mg} / \mathrm{kg}$ P.O. & $\begin{array}{c}13.5 \pm 1.4 \\
(3.449)\end{array}$ & $\begin{array}{c}16.8 \pm 0.7 \\
(0.705), \mathbf{2 4 . 4 \%}\end{array}$ & $\begin{array}{c}18.6 \pm 0.6 \\
(0.617), 37.7 \%\end{array}$ & $\begin{array}{c}19.5 \pm 0.7 \\
(0.766), 44.4 \%\end{array}$ & $\begin{array}{c}20.3 \pm 0.6 \\
(0.617), 50.37 \%\end{array}$ \\
\hline
\end{tabular}

$* \mathrm{P}<0.001$ Control value vs respective drug group. ${ }^{* *} \mathrm{P}<0.001$ standard vs Ap-10 $(n=6)$, One-way ANOVA; SEM = Standard error of mean, $\mathrm{SD}=$ Standard deviation

Table 2: Effect of apigenin on Eddy's Hot plate model in Mice

\begin{tabular}{|c|c|c|c|c|c|c|}
\hline \multirow[b]{3}{*}{ Drug } & \multicolumn{6}{|c|}{ Analgesic effect of Apigenin on Eddy's hot plate response in Mice } \\
\hline & \multicolumn{6}{|c|}{ Reaction time in a sec (mean $\pm S E M), S D, \%$ increase in reaction time } \\
\hline & Dose/route & Basal & 30min & $60 \mathrm{~min}$ & $120 \mathrm{~min}$ & $180 \mathrm{~min}$ \\
\hline $\begin{array}{l}\text { Normal } \\
\text { saline(control) }\end{array}$ & $2 \mathrm{ml} \mathrm{P.O.}$ & $\begin{array}{c}4.3 \pm 0.34 \\
(0.816)\end{array}$ & $\begin{array}{c}4.6 \pm 0.21 \\
(0.516), 7.62 \%\end{array}$ & $\begin{array}{c}4.8 \pm 0.31 \\
(0.752), 11.54 \%\end{array}$ & $\begin{array}{c}5.3 \pm 0.34 \\
(0.816), \mathbf{2 3 . 2 5 \%}\end{array}$ & $\begin{array}{c}5.0 \pm 0.5 \\
(1.264), 16.27 \%\end{array}$ \\
\hline $\begin{array}{l}\text { Tramadol } \\
\text { (Standard) }\end{array}$ & $25 \mathrm{mg} / \mathrm{kg}$ I.P. & $\begin{array}{l}5.1 \pm 0.4 \\
(0.983)\end{array}$ & $\begin{array}{c}7.5 \pm 0.4^{*} \\
(0.516), 47.05 \%\end{array}$ & $\begin{array}{c}11.1 \pm 0.7^{*} \\
(1.722), 117.6 \%\end{array}$ & $\begin{array}{c}13.1 \pm 0.7^{*} \\
(1.834), 156.8 \%\end{array}$ & $\begin{array}{c}13.3 \pm 0.8^{*} \\
(2.065), 160.7 \%\end{array}$ \\
\hline $\begin{array}{l}\text { Apigenin- } \\
10 \mathrm{mg}\end{array}$ & 10mg/kg P.O. & $\begin{array}{l}4.5 \pm 0.2 \\
(0.547)\end{array}$ & $\begin{array}{c}4.8 \pm 0.4^{b} \\
(0.752), 6.66 \%\end{array}$ & $\begin{array}{c}5.8 \pm 0.4^{b} \\
(0.983), \mathbf{2 8 . 8 \%}\end{array}$ & $\begin{array}{c}6.5 \pm 0.2^{b} \\
(0.547), 44.4 \%\end{array}$ & $\begin{array}{c}6.4 \pm 0.3^{b} \\
(0.836), 42.2 \%\end{array}$ \\
\hline $\begin{array}{l}\text { Apigenin- } \\
20 \mathrm{mg}\end{array}$ & $20 \mathrm{mg} / \mathrm{kg}$ P.O. & $\begin{array}{l}4.8 \pm 0.3 \\
(0.752)\end{array}$ & $\begin{array}{c}7.3 \pm 0.4^{*} \\
(0.983), 52.8 \%\end{array}$ & $\begin{array}{c}9.6 \pm 0.4^{*} \\
(1.032), 99.37 \%\end{array}$ & $\begin{array}{c}10.8 \pm 0.4 * a \\
(1.169), 125 \%\end{array}$ & $\begin{array}{c}11.8 \pm 0.4 * \\
(1.169), 139 \%\end{array}$ \\
\hline $\begin{array}{l}\text { Apigenin- } \\
40 \mathrm{mg}\end{array}$ & 40mg/kg P.O. & $\begin{array}{l}4.6 \pm 0.3 \\
(0.816)\end{array}$ & $\begin{array}{c}6.6 \pm 0.2^{*} \\
(0.516), 43.47 \%\end{array}$ & $\begin{array}{c}9.3 \pm 0.2 * a \\
(0.516), 102 \%\end{array}$ & $\begin{array}{c}10.1 \pm 0.4^{*} \\
(0.983), 119 \%\end{array}$ & $\begin{array}{c}11.3 \pm 0.4^{*} \\
(1.211), 145.6 \%\end{array}$ \\
\hline
\end{tabular}

* $\mathrm{P}<0.001$ control vs respective group, a $\mathrm{P}<0.05$ Tramadol vs respective group, ${ }^{\mathrm{b}} \mathrm{P}<0.001$ Tramadol vs respective group. 


\section{DISCUSSION}

Natural products have been widely used as good alternatives to produce new drugs and therapeutic agents for combating disease ${ }^{20}$. In current study apigenin expressed potent analgesic activities in hot plate test in the mice models as well as tail-flik test in Wister albino rats. Hot plate and tail-flick tests are used for evaluation of the central pain at the supraspinal and spinal levels possibly acting on a descending inhibitory pain pathway ${ }^{21}$. The tail-flick response is believed to be a spinally mediated reflex and the paw-licking hot plate response is more complex supraspinal organized behaviour ${ }^{22}$. The effectiveness of analgesic agents in the tail-flick pain model is highly comparable with relief of human pain Perception ${ }^{23}$.In both the model's data showed that the apigenin dose dependently increased the pain threshold. The latency profile of different dose of apigenin were comparable with standard drug tramadol. The $\mu$ receptor stimulation is generally associated with pain relief and has been shown to be potent in regulating thermal pain. Non-analgesic effects through the $\mu$ receptors include respiratory depression and physical dependence. Activation of $\mu 2$ opioid subtype leads to spinal analgesia and commonly causes constipation as adverse effect ${ }^{24}$. Therefore, taking all these data together we believe that the analgesic activity of apigenin is most likely to be mediated by central action (spinally and supraspinally) and indicates a tramadol like mechanism by binding with opioid receptors with producing minimal side effect. Apigenin could be better substitute for the opioid's drugs like morphine for the management of chronic pain like cancer ${ }^{25}$.

\section{CONCLUSION}

Apigenin has analgesic activity in hotplate and tail-flik test in rodent. Further in vitro and in vivo studies are recommended to further investigate the detailed action and mechanism of actions as well as to increase the efficacy of apigenin for clinical application

\section{REFERENCES}

1. Kanodia L, Das S: A comparative study of analgesic property of whole plant and fruit extracts of Fragaria vesca in experimental animal models. Bangladesh J Pharmacol 2008; 4: $35-38$

2. Michel YB, Dubois Christopher G, Allen HL: Chronic pain management. In Wylie and Churchil-Davidson's A practice of Anaesthesia. 7th edition. Edited by: Healy TEJ, Knight PR. London: Hodder Arnold; 2003;1139-1235.

3. Thomas MC: Diuretics, ACE inhibitors and NSAIDs - the triple whammy. Med J Aust 2000;172:184-185.

4. Kayyalap SO: Medicinal pharmacology, in terms of rational treatment (Rasyonel tedavi yonunden tibbi farmakoloji). Ankara: Hacettepe- Tas Ltd Sti; 1998.

5. Whelton A, Stout RL, Spilman PS, Klassen DK. Renal effects of Ibuprofen, Piroxicam and Sulindac in patients with asymptomatic renal failure. A prospective, randomized cross over comparison. Ann Intern Med 1990; 12:568-76.

6. Marasco WA, Gikas PW, Azziz-Baumgartner R, Hyzy R, Eldredge $\mathrm{CJ}$, Stross J. Ibuprofen-associated renal dysfunction.
Pathophysiologic mechanisms of acute renal failure, hyperkalemia, tubular necrosis and proteinuria. Arch Intern Med 1987; 147:2107-16.

7. DiMasi JA, Ronald WH, Henry GG. The price of innovation: new estimates of drug development costs. I Health Economics 2003;22: 151-185

8. Ovando C, Hernandez D, Hernandez E, et al. Chemical studies of anthocyanins: a review. Food Chem,2009;113: 859-871.

9. Lee Y, Yuk D, Lee J, et al. Epigallocatechin-3-gallate prevents lipopolysaccharide-induced elevation of $\beta$-amyloid generation and memory deficiency. Brain Res, 2009; 1250: 164-174.

10. Middleton, E. The flavonoids as potential therapeutic agents. In Immunopharmaceuticals, ed. E.S. Kimball, 1996;227-257. Boca Raton: CRC Press.

11. Ornano, L.Venditti, A.; Donno, Y.; Sanna, C.; Ballero, M.; Bianco, A. Phytochemical analysis of non-volatile fraction of Artemisia caerulescens subsp. densiflora (Viv.) (Asteraceae), an endemic species of La Maddalena Archipelago (SardiniaItaly). Nat. Prod. Res. 2016;30:920-925.

12. Rossi, M.; Negri, E.; Lagiou, P.; Talamini, R.; Dal Maso, L.; Montella, M.; Franceschi, S.; La Vecchia, C. Flavonoids and ovarian cancer risk: A case-control study in Italy. Int. J. Cancer 2008;123:895-898.

13. Bosetti, C, Spertini, L.; Parpinel, M.; Gnagnarella, P.; Lagiou, P.; Negri, E.; Franceschi, S.; Montella, M.;Peterson, J.; Dwyer, J.; et al. Flavonoids and Breast Cancer Risk in Italy. Cancer Epidemiol. Biomark. Prev. 2005;14:805-808.

14. Hoensch, H.; Groh, B.; Edler, L.; Kirch, W. Prospective cohortcomparison of flavonoid treatment in patients with resected colorectal cancer to prevent recurrence. World J. Gastroenterol. 2008;14:2187-2193.

15. Kumar, H.; More, S.V.; Han, S.-D.; Choi, J.-Y.; Choi, D.-K. Promising Therapeutics with Natural Bioactive Compounds for Improving Learning and Memory-A Review of Randomized Trials. Molecules, 2012;17:10503-10539.

16. Smolinski AT, Pestka JJ. Modulation of lipopolysaccharideinduced proinflammatory cytokine production in vitro and in vivo by the herbal constituents apigenin (chamomile), ginsenoside $\mathrm{Rb}(1)$ (ginseng) and parthenolide (feverfew). Food Chem Toxicol. 2003;41:1381-1390.

17. D'Amour FE, Smith DL. A method for determining loss of pain sensation. J Pharmacol Exp Ther 1941; 72: 74-79

18. Prempeh ABA, Mensah AJ. Analgesic activity of crude aqueous extract of the root bark of Zanthoxylum Xanthoxyloides. Ghana Med J 2008 June; 42(2): 79-84

19. M.V. Amberkar, S. Tara, M. Kumari, K.L. Bairy, and S. Shenoy, Evaluation of anti-inflammatory and analgesic activities of alcoholic extract of Kaempferia galanga in rats. Indian Journal of Physiology and Pharmacology, 2011;55(1):13-24.

20. Abdelkhalek NK, Ghazy EW, Abdel-Daim MM. Pharmacodynamic interaction of Spirulina platensis and deltamethrin in freshwater fish Nile tilapia, Oreochromis niloticus: impact on lipid peroxidation and oxidative stress. Environ Sci Pollut Res Int. 2015; 22:3023-3031. 
21. Richardson JD, Aanonsen L, Hargreaves KM and et al. Antihyperalgesic effects of spinal cannabinoids. European Journal of Pharmacology 1998; 345: 145-153

22. Chapman CR, Casey KL, Dubner R, Foley KM, Gracely RH, Reading AE. Pain measurement: an overview. Pain 1985; 22: 1-31

23. Grumbach $L$, The production of analgesic activity in man by animal testing. In: R.S. Knighton and Dumke P R, Editors, Pain, Little Brown and Co., Boston 1966: 163-182.
24. Dhawan BN, Cesselin F, Raghubir R and et al. Classification of opioid receptors. Pharmacological Reviews 1996; 48: 567592.

25. O'Brien CP. Drug addiction and drug abuse. In: Brunton LL, Lazo JS, Parker KL, eds. Goodman? And Gilman's the pharmacological basis of therapeutics. New York, McGrawHill 2006:617.

Source of Support: The author(s) received no financial support for the research, authorship, and/or publication of this article.

Conflict of Interest: The author(s) declared no potential conflicts of interest with respect to the research, authorship, and/or publication of this article.

For any question relates to this article, please reach us at: globalresearchonline@rediffmail.com New manuscripts for publication can be submitted at: submit@globalresearchonline.net and submit_ijpsrr@rediffmail.com 